\title{
Psychological Peculiarities of Understanding Communicative Behavior of People from English-Speaking Countries
}

\section{Психологічні особливості розуміння комунікативної поведінки людей з англомовних країн}

\section{Ernest Ivashkevych}

Ph.D. in Psychology, Senior Lecturer of the Department of Practice of English, Translator, Rivne State University of the Humanities, Rivne (Ukraine)

ORCID ID: https://orcid.org/0000-0001-7219-1086

Researcher ID: http://www.researcherid.com/rid/F-3865-2019

E-mail: ivashkevych.ee@gmail.com

\section{Ернест Івашкевич}

Кандидат психологічних наук, старший викладач кафедри практики англійської мови, перекладач, Рівненський державний гуманітарний університет, м. Рівне (Україна)

\section{ABSTRACT}

The aim of this research is to define psychological peculiarities of understanding communicative behavior of people from English-speaking countries.

Methods of the research. As for general scientific methods, the method of induction, deduction, analysis and synthesis, comparative and descriptive methods and explanatory one are used.

The results of the research. It was shown that the perception and understanding of communicative behavior of people from English-speaking countries

Address for correspondence, e-mail: kpnu_lab_ps@ukr.net Copyright: (C) Ivashkevych Ernest

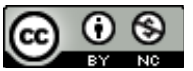

The article is licensed under CC BY-NC 4.0 International

(https://creativecommons.org/licenses/by-nc/4.0/)

(C) Ivashkevych Ernest

DOI (article): https://doi.org/10.32626/2227-6246.2021-51.33-53 
DOI: https://doi.org/10.32626/2227-6246.2021-51

2021. ВиПУСК 51

in a great degree was actualized through the image. The latter is not just the result of the person's imagination, but a visual generalization that accompanies the verbal explication of the man's thoughts through the Englishmen / women pointing gestures. If the pointing gesture is separated from the whole paradigm of perception as a certain object of interest from the environment, especially situational, then the separation, for example, is a part of this object in relations to a specially selected or constructed space indicates the supra-situational attitude of the recipient to a certain object and the creation of the most stable way of existence of the object itself, in addition to its connections with the pointing gesture. Thus, the pointing gesture is transformed into a paradigm of conditional space, further transformations of which facilitates the emergence of the "pointing field» in the system of the perception and understanding of communicative behavior of people from English-speaking countries.

Conclusions. The actualization of communicative behavior of people from English-speaking countries by recipients takes place in a conditional space close to a real life. Communicative behavior of people from English-speaking countries contributes to the fact that speech activity will be "grouped» around the image and creative practices. Conditionally, space becomes a paradigm of the most significant and valuable content, which initially embodied a certain image, specially created by the addressee. In other words, the selection of this speech image became the basis for the construction of the individual model of the world by recipients. Ritualized real actions, which contain the "products" of all kinds of creative practices in their structure, represent a symbolic form of the primary image, which is created by recipients from the very beginning of the actualization of communicative behavior of people from English-speaking countries.

Key words: communicative behavior, people from English-speaking countries, the image, visual generalization, construction of the individual model of the world.

\section{Introduction}

Speaking about communicative behavior of people from English-speaking countries, we have to emphasize on the problem of the appearance and communication of English people, to show main problems and the ways of their solving (Mykhalchuk \& Bihunova, 2019). First of all, we have to note that England is one of four distinct regions of the United Kingdom, (C) Ivashkevych Ernest

DOI (article): https://doi.org/10.32626/2227-6246.2021-51.33-53 
which includes Wales, Scotland, and Northern Ireland. England's population is approximately 47 million people.

It is important to note that the Scots, Welsh and Irish are not English, and they are often offended when referred to English speaking world. Additionally, citizens of the U. K. do not consider themselves, as European. Unfortunately, they are usually grouped due to the part of people's membership in the European Union.

The English are very proud of their heritage and history. Along with their contributions to the world of today, several famous writers came from England. Some of the most famous are W. Shakespeare, T. S. Eliot, and G. Chaucer. This century England has seen many influential daughters and sons. The Beatles, Winston Churchill, and Queen Elizabeth II have all played a tremendous role in England's presence in the contemporary world.

The scientific analysis for England illustrates their strong feelings towards individualism and masculinity (Гончарук \& Онуфрієва, 2018). The power distance and uncertainty avoidance are ranked considerably as less important ones (Максименко, Ткач, Литвинчук \& Онуфрієва, 2019). Long-term orientation ranks the lowest, indicating that change in England that can be achieved more rapidly than in many other countries (Mykhalchuk \& Ivashkevych, 2019).

According to these, the aim of this research is to define psychological peculiarities of understanding communicative behavior of people from English-speaking countries.

In order to achieve the aim stated in our research, we have to complete a set of the following objectives: to distinguish the United Kingdom - Great Britain - England Appearance, which in a great degree influences the communicative behavior of English speaking people; to describe the United Kingdom - Great Britain - England Communicative Behavior; to determine the United Kingdom - Great Britain - England Patterns of Communications; to describe meeting and greeting in England; to

(C) Ivashkevych Ernest

DOI (article): https://doi.org/10.32626/2227-6246.2021-51.33-53 
DOI: https://doi.org/10.32626/2227-6246.2021-51

2021. випуск 51

characterize body language in England; to describe a corporate culture in England; to show dining and entertainment in England; to characterize dress and gifts in England; to describe helpful hints in England. All these are factors of Communicative Behavior of people from English-speaking countries.

\section{Methods of the research}

Taking into account the importance of the conventional methods of scientific research while dealing with the object of our article, the most substantial part of the methodological base for this research has been developed by us. As for general scientific methods, the method of induction, deduction, analysis and synthesis, comparative and descriptive methods and explanatory ones were also used quite successfully.

\section{Results and their discussion}

Analyzing Predominantly Christian countries, the primary correlation between religion and the Geert Hofstede Dimensions is a High Individualism Ranking. This indicates that predominantly Christian countries have a strong belief for the person's individuality, with individual rights being paramount within the society. People in these countries may tend to form a larger number of looser relationships.

So, we have to distinguish the United Kingdom - Great Britain - England Appearance, which in a great degree influences the communicative behavior of English-speaking people:

1. Business attire rules are somewhat relaxed in England, but conservative dress is still very important for both men and women, whether you're interviewing for a professional Tesco jobs or a restaurant position.

2. Dark suits, usually black, blue or gray are quite acceptable.

3. Men's shirts should not have pockets; if they do, the pockets should always be kept empty. Additionally, men should wear solid or patterned ties, while avoiding striped ties.

(C) Ivashkevych Ernest

DOI (article): https://doi.org/10.32626/2227-6246.2021-51.33-53 
DOI: https://doi.org/10.32626/2227-6246.2021-51

4. Men wear laced shoes, not loafers.

5. Business women are not as limited to colors and styles as men are, though it is still important to maintain a conservative image.

Let's describe the United Kingdom - Great Britain - England Communicative Behavior:

1. Always be punctual in England. Arriving a few minutes early for safety is acceptable.

2. Decision-making is slower in England than in the United States; therefore it is unwise to rush the English into making a decision.

3. A simple handshake is the standard greeting (for both men and women) for business occasions and for visiting home.

4. Privacy is very important to the English. Therefore asking personal questions or intensely staring at another person should be avoided.

5. Eye contact is seldom kept during British conversations.

6. To signal that something is to be kept confidential or secret, tap your nose.

7. Personal space is important in England, and one should maintain a wide physical space when conversing. Furthermore, it is considered inappropriate to touch others in public.

8. Gifts are generally not a part of doing business in England.

9. A business lunch will often be conducted in a pub and will consist of a light meal and perhaps a pint of ale.

10. When socializing after work hours, do not bring up the subject of the activity.

11. When dining out, it is not considered polite to toast those who are older than this person.

Now it is correct to determine United Kingdom - Great Britain - England Patterns of Communications:

1. America, Britain, Canada, Australia and other countries have included nations divided by a common language.

C) Ivashkevych Ernest

DOI (article): https://doi.org/10.32626/2227-6246.2021-51.33-53 
DOI: https://doi.org/10.32626/2227-6246.2021-51 2021. випУСК 51

2. In England English is the official language, but it should be noted that Queen's English and American English are very different.

3. Ordinary vocabulary can differ between two countries.

4. Loud talking and disruptive behavior should be avoided.

5. One gesture to avoid is the $\mathrm{V}$ for Victory sign, done with the palm facing the person. This is a very offensive gesture.

6. If a man has been knighted, he is addressed, as: "Sir and his first name», for example: «Sir John. If writing a letter, the envelope is addressed - «Sir First name and Last name», in such a way: «Sir John Roberts» .

So, let us describe the communicative behavior of people in England nowadays. Four countries make up the United Kingdom of Great Britain and Northern Ireland - England, Scotland, Wales and Northern Ireland. Residents of any of these countries may be called «British». Use «English», «Scot» or «Scotsman», «Welsh» and «Irish» or «Northern Irish» only when it is certain of a person's heritage. While four countries share many customs, each has its own set of cultural nuances.

In England politeness, reserve and restraint are admired. The English are courteous, unassuming and they are very proud of their long and rich history.

Scots are passionate about their country, guarding its uniqueness and refusing to go along with English ideas. While cool and aloof externally, they are extremely sentimental about their family and their country. Overall Scots are free of class consciousness and social elitism, except in religion.

Generally, Protestants mix only with Protestants and Catholics, and they mix only with Catholics. Scots have a keen, subtle sense of humor and value generosity, respectability. Wales has been a part of the United Kingdom for more than 400 years, but has kept its own language, literature and traditions. The most residents of Wales are of Welsh or English heritage. Many immigrants from former British colonies and other parts of U.K., for example Welsh take a great pride for their country (C) Ivashkevych Ernest

DOI (article): https://doi.org/10.32626/2227-6246.2021-51.33-53 
and their heritage. The Welsh love to sing and talk and spend much of their free time with their families (Batel, 2020).

Two-thirds of the Northern Irish have Scottish or English roots. The others are of Irish descent. Irish value friendliness, sincerity and nature. They dislike pretentious behavior and possess a strong ethic activity. Family ties are very important in Northern Ireland.

Let us describe meeting and greeting in England:

1. The British are reserved, which may cause them to appear cool and indifferent or overly formal. In fact, they are very friendly and helpful to foreigners.

2. Shake hands with everyone present - men, women, and children - at business and social meetings. Shake hands again when leaving.

3. Handshakes are light - not firm.

4. Women should extend their hand to men first.

5 . Use the last names and the appropriate titles until specifically invited by your British hosts or colleagues to use their first names.

Let's characterize body language in England:

1. The British are not back slappers or touches and generally do not display affection in public.

2. Hugging, kissing and touching are usually reserved for family members and very close friends.

3. The British like a certain amount of personal space. Do not stand too close to another person or put your arm around someone's shoulder.

4. Staring is considered rude.

Communicative behavior in a large degree depends on $a$ corporate culture in England:

1. In Great Britain punctuality is important for business meetings. Be on time.

2. Brits prefer a congenial business relationship, but tend to get right down to business after a few moments of polite conversation.

(C) Ivashkevych Ernest

DOI (article): https://doi.org/10.32626/2227-6246.2021-51.33-53 
DOI: https://doi.org/10.32626/2227-6246.2021-51 2021. виПУСК 51

3. Business is well initiated through a well-connected third party.

4. The Board of Directors is the source of power and the principal decision making unit in a company. Formal approval of the board is required for most decisions. Decisions may be slow in their modeling.

5. Expect formalities and protocol to be observed for business, especially in London.

6. Business organization traditionally is multi-layered with a vertical chain of a command. A network of committees, formal and informal, is existed in larger companies. Group consensus is preferred to individual initiative.

7. In older companies, business still centers around the «old boy network» with prep schools, universities and family ties being of great importance. Newer companies are more progressive.

8. Meetings should be scheduled well in advance.

9. Meetings generally have a concrete objective, such as: making a decision, developing a plan or arriving for any agreement.

10. Presentations should be detailed and subdued.

11. Scots are known for being skilled business persons, priding themselves for being internationalists. They also are suspicious of "go-getters» and have gained respect success only when it is achieved over time.

Let's show dining and entertainment in England:

1. Summon a waiter by raising your hand. Don't wave or shout.

2. The most business entertaining is done restaurants or pubs over lunch. The host, the one who extends the invitation, pays the bill.

3. British business may invite you to watch cricket or to the regatta. Both are prestigious events. Wear your tweed sport coat or blue blazer.

(C) Ivashkevych Ernest

DOI (article): https://doi.org/10.32626/2227-6246.2021-51.33-53 
4. The invitation to someone's home is more common in England than in the rest of Europe.

5. Do not discuss business at dinner in someone's home unless the host initiates the conversation.

6. In England, when invited to someone's home, arrive at least 10-20 minutes after the stated time. Never arrive early. In Scotland and Wales, arrive on time.

7. A male guest of honor is seated at the head of the table or to the right of the hostess. A female guest of honor is seated to the right of the host.

8. Wait for your host to begin eating before you eat.

9. Host or hostess always initiates the first toast, which is usually only given at a formal dinner.

10. At a formal dinner, do not smoke until after the toast to the Queen or until otherwise indicated by the host.

11. Keep your hands on the table at all times during the meal - not on your lap. However, take care to keep your elbows off the table.

12. When finished eating, place knife and fork side by side on the plate at the 5:25 position.

13. You should leave a very small amount of food on your plate when finished eating.

14. The guest of honor should initiate leaving a party.

15. When the host folds his / her napkin, this signals that the meal is over.

16. Leave a dinner party shortly after dinner ends.

17. Write a thank you note to the hostess.

18. It is considered impolite to ask for a tour of your host's home.

19. Entertain anyone who has entertained you, but don't try to impress British guests with an extravagant dinner. The Brits prefer understatement.

Dress in England is also unique, it also influences communicative behavior of English people:

(c) Ivashkevych Ernest

DOI (article): https://doi.org/10.32626/2227-6246.2021-51.33-53 
DOI: https://doi.org/10.32626/2227-6246.2021-51 2021. випУСК 51

1. People in the larger cities dress more formally, especially in London.

2. Men and women wear wools and tweeds for casual occasions. Slacks, sweaters and jackets are appropriate for men and women.

3. Avoid striped ties that are copies of British regimentals.

4. Men's clothing often expresses affiliation rather than style. Ties are the most important symbols. School, army, university or club ties are worn.

5. For business meetings, men should wear dark suits and ties. Women should wear suits, dresses or skirts and blouses.

6. Do not wear a blazer to work. A blazer is country or weekend wear.

7. For formal events men may wear black ties, business suits, morning coats or tails. Inquire which something or somebody is required. Women generally wear cocktail suits or dresses.

Very specific are gifts in England, and communicative behavior also depends on them:

1. Gifts are normally not exchanged in business settings.

2. When invited to someone's home, always bring a small gift for the hostess. Give flowers, chocolates, wine, champagne or books. Present the gift upon arrival.

3. Gifts are opened upon receiving.

4. It is polite to send flowers in advance of a dinner party. Do not send white lilies, which denote death.

Let us describe helpful hints in England:

1. Men should open doors for women and stand when a woman enters a room.

2. Always hold the door for a person following behind you.

3. Honor rank when entering a room. Allow higher rank to enter first.

4. Don't insult a royal family or show a great interest in their private lives.

(C) Ivashkevych Ernest

DOI (article): https://doi.org/10.32626/2227-6246.2021-51.33-53 
5. Respect the British desire for privacy. Don't ask personal questions, such as where a person lives or what a person does for his / her profession or job. Don't talk about money.

6. Do not violate a queue. It is considered very rude to push ahead in a line.

7. Do not shout or be loud in public places and don't use excessive, demonstrative hand gestures when speaking.

8. Staring is considered quite impolite.

9. Do not be too casual, especially with the English language.

10. The English avoid speaking in superlatives. «I am quite pleased», means, that people are extremely happy.

11. Never try to sound British or mimic their accent.

12. Humor is ever-present in English life. It is often selfdeprecating, ribbing, sarcastic, sexist or racist. Try not to take offense.

13. In Scotland, kilts are worn by men at formal occasions (for ex. a black tie, weddings, etc.). Don't make jokes about or ask a Scot what he wears under his kilt.

14. In Northern Ireland, religion and politics have created conflict for many years. Avoid these discussing topics if it is possible.

There are some details which are useful and for distinguishing the communicative behavior of English people. Especially for women for distinguishing their communicative behavior:

1. The "Old Boy Network» is alive and well in the United Kingdom. However, women are becoming more common in managerial positions in the United Kingdom than in most EC countries, especially in service industries and public sector jobs.

2. Foreign women will have little difficulty conducting business in Great Britain.

3. Don't be insulted if someone calls you love, dearie, or darling. These are commonly used and not considered rude.

(C) Ivashkevych Ernest

DOI (article): https://doi.org/10.32626/2227-6246.2021-51.33-53 
DOI: https://doi.org/10.32626/2227-6246.2021-51

2021. випуск 51

4. It is acceptable, but may be misconstrued, for a foreign woman to invite an English man to dinner. It is best to stick with lunch.

5. If a woman would like to pay for a meal, she should state this at the outset.

6. Crossing your legs at the ankles, not at the knees, if it is proper.

So, we propose some basic types of nonverbal communication and body language of English people. There are many different types of nonverbal communication. If taking together, the following nonverbal signals and cues for productive communication depend on the person's interest and investment from the side of others.

Facial expressions. The human face is extremely expressive, it is able to express countless emotions without saying a word. And unlike some forms of nonverbal communication, facial expressions are universal. The facial expressions for happiness, sadness, anger, surprise, fear, and disgust are the same among different cultures.

Body movements and posture. Consider how your perceptions of people are affected by the way they sit, walk, stand up or hold their head. The way you move and carry yourself, communicate in a paradigm of wealth of information around the world. This type of nonverbal communication includes your posture, bearing, stance, and subtle movements.

Gestures. Gestures are woven into the fabric of our daily lives. We wave, point, beckon and use our hands when we're arguing or speaking animatedly -expressing ourselves with gestures often without thinking. However, the meaning of gestures can be very different across cultures and regions, so it's important to be careful to avoid misinterpretation.

Eye contact. Since the visual sense is dominant for the most people, eye contact is the especially important type of nonverbal communication. The way you look at someone can communicate many things, including interest, affection, hostility or attrac(C) Ivashkevych Ernest

DOI (article): https://doi.org/10.32626/2227-6246.2021-51.33-53 
tion. Eye contact is also important in maintaining the flow of conversation and for gauging the other person's response.

Facial Expression. The face is more highly developed as an organ of expression of people. Some of these become quite habitual, almost fixed into the chronic muscular structure of the face. For instance, in some parts of the South the regional pattern of holding the jaw tight creates a slight bulge in the temples due to an overgrowth or "hypertrophy" of those jaw muscles that arise in this or that area. This creates a characteristic appearance. The squint of people who live a lot in the sun is another example.

In such a way there are many different meanings in different cultures, and what may be friendly in one country or region can be insult for partners of communication.

Touch. How one person touches another partner of communication with a great deal of information: "Is a grip gentle or firm, and does one hold the other person on the back of the upper arm, on the shoulder or in the middle of the back. Is the gesture a push or a tug? Is the touch closer to a pat, a rub or a grabbing? People have different areas of personal intimacy, and this refers not only to the sexual dimension, but also the dimension of self-control. Many schoolchildren are particularly sensitive to any touching that could be interpreted as patronizing or undue familiarity. Even the angle of one's holding another's hand might suggest a hurrying or coercive implicit attitude, or on the other hand, a respectful, gentle, permission-giving approach.

Locomotion: The style of physical movement in space also communicates a great deal, as well as affecting the feelings of the person doing the moving:

\begin{tabular}{|l|l|l|l|}
\hline Slither & Crawl & Totter & Walk \\
\hline Stroll & Shuffle & Hurry & Run \\
\hline Jog & Spring & Tiptoe & March \\
\hline Jump & Hop & Skip & Climb \\
\hline swing & Acrobatics & Swim & Slink \\
\hline
\end{tabular}

DOI (article): https://doi.org/10.32626/2227-6246.2021-51.33-53

C Ivashkevych Ernest 
DOI: https://doi.org/10.32626/2227-6246.2021-51

Facing: This is the way an action is done.

\begin{tabular}{|l|l|l|l|}
\hline Jerky & Pressured & Nervous & Gradual \\
\hline Graceful & Fatigued & Tense & Easy \\
\hline Shaky & Deliberate & Furtive & Clumsy \\
\hline
\end{tabular}

A related variable is the time it takes to react to a stimulus, called «latency of response». Some people seem to react to different questions, interact in conversations or are slower or faster «on the uptake» than others.

Nonverbal communication can be divided into several categories: facial expressions, head movements, hand and arm gestures, physical space, touching, eye contact and physical postures.

Facial expressions are also different:

- Although smiling is the expression of happiness in the most cultures, it can also signify other emotions. Some Chinese, for example, may smile when they are discussing something sad or uncomfortable.

- Winking has very different connotations in different cultures. In some Latin American cultures winking is a romantic or sexual invitation. In Nigeria, Yorubas may wink at their children if they want them to leave the room. Many Chinese consider winking to be rude.

- In Hong Kong, it is important not to blink one's eyes conspicuously, as this may be seen as a sign of disrespect and boredom.

- Some Filipinos will point to an object by shifting their eyes toward it or pursing their lips, and point with their mouth, rather than using their hands.

- Some Venezuelans may use their lips to point at something, because pointing with a finger is impolite.

- Expressions of pain or discomfort such as crying are also specific to various cultures; some cultures may value a stoic affect while others may encourage a more emotive state. (C) Ivashkevych Ernest

DOI (article): https://doi.org/10.32626/2227-6246.2021-51.33-53 
DOI: https://doi.org/10.32626/2227-6246.2021-51

2021. випуск 51

Expressions of pain or discomfort are also learned from one's family illness experiences, expressions and idioms of distress.

\begin{tabular}{|l|l|}
\hline Kinesics & $\begin{array}{l}\text { body motions (blushes, shrugs, eye movement, } \\
\text { foot-tapping, drumming fingers) }\end{array}$ \\
\hline Proxemics & $\begin{array}{l}\text { spatial separation (in relation both the social and } \\
\text { physical environment) }\end{array}$ \\
\hline Haptics & touch \\
\hline Oculesics & eye contact \\
\hline Chronemics & use of time, waiting, pausing \\
\hline Olfactics & smell \\
\hline Vocalics & tone of voice, timbre, volume, speed \\
\hline Sound Symbols & grunting, mmm, er, ah, uh-huh, mumbling, \\
\hline Silence & absence of sound (muteness, stillness, secrecy) \\
\hline Adornment & clothing, jewellery, hairstyle \\
\hline Posture & position of the body (characteristic or assumed) \\
\hline Locomotion & walking, running, staggering, limping \\
\hline Expression & frowns, grimaces, smirks, smiles, pouting \\
\hline $\begin{array}{l}\text { Form Main } \\
\text { Function (in } \\
\text { some cultures) }\end{array}$ & $\begin{array}{l}\text { nod (Yes); repeating; shrug (I don't know); sub- } \\
\text { stituting; scratch head, quizzical look; comple- } \\
\text { menting; tone of voice, pointing; accenting; hand } \\
\text { raised; regulating, turn taking; head shake; con- } \\
\text { tradicting; eye movements; staring / looking down } \\
\text { or away; dominating / submitting; raised fist; } \\
\text { aggression; hand-shake; socializing; touching, } \\
\text { kissing; arousal; over-adornment; boasting. }\end{array}$ \\
\hline
\end{tabular}

\section{Conclusions}

So, we'll propose some psychological conditions of the perception and understanding of communicative behavior of people from English-speaking countries:

1. We think that the perception and understanding of communicative behavior of people from English-speaking countries in a great degree is actualized through the image. The latter is not just the result of the person's imagination, but a visual generalization that accompanies the verbal explication of the

(C) Ivashkevych Ernest

DOI (article): https://doi.org/10.32626/2227-6246.2021-51.33-53 
man's thoughts through the Englishmen / women pointing gestures. If the pointing gesture is separated from the whole paradigm of perception as a certain object of interest from the environment, especially situational, then the separation, for example, is a part of this object in relations to a specially selected or constructed space indicates the supra-situational attitude of the recipient to a certain object and the creation of the most stable way of existence of the object itself, in addition to its connections with the pointing gesture. Thus, the pointing gesture is transformed into a paradigm of conditional space, further transformations of which facilitates the emergence of the "pointing field" in the system of the perception and understanding of communicative behavior of people from English-speaking countries.

2 . In the initial period of formation of communicative behavior of people from English-speaking countries of recipients, when language and comprehension are based on the structure of meaning, the leading role in these processes is played by subject affiliation, visual, visual image (= image), performing the role of «internal form» support of communicative behavior of people from English-speaking countries and further - verbal thinking.

3. The actualization of communicative behavior of people from English-speaking countries by recipients takes place in a conditional space close to a real life. Communicative behavior of people from English-speaking countries contributes to the fact that speech activity will be "grouped» around the image and creative practices. Conditionally, space becomes a paradigm of the most significant and valuable content, which initially embodied a certain image, specially created by the addressee. In other words, the selection of this speech image became the basis for the construction of the individual model of the world by recipients. Ritualized real actions, which contain the "products» of all kinds of creative practices in their structure, represent a symbolic form of the primary image, (C) Ivashkevych Ernest

DOI (article): https://doi.org/10.32626/2227-6246.2021-51.33-53 
which is created by recipients from the very beginning of the actualization of communicative behavior of people from English-speaking countries.

4. Stimulating the development of communicative behavior of people from English-speaking countries of recipients allows us to assert the fact of the coincidence of the structure of the subject action of the person with the structure of the expanded statement (the addressee - the action - the object). In this case, the special significance of the game in the development of communicative behavior of people from English-speaking countries can be argued about the unifying (between practice and foreign language) nature of the image (for us it is a game) activities. This does not mean a separate action, but an art system that provides the dominant role of the recipients as a figure who, by the conditions of «imaginary situation" was excluded into the space of everyday life. The actions associated with it (are usually irrelevant, conditional), and the depicted objects will resemble a simple, everyday situation, such as playing with a toy, or drawing, dancing, etc.). It is the system that is reflected in foreign language speech. The conditional visual system and the system of foreign language speech are closely interconnected and they are in a situation of mutual generation. That is why communicative behavior of people from English-speaking countries is a link, not a "mediator» between the practice and the language, but a speech-generating mechanism.

5. By stimulating the communicative behavior of people from English-speaking countries of recipients, the addressee creates an image that focuses on the image in a situation of limited conditional field. It is the mechanism that brings learning situations closer to real ones, which will be continued in the next life of recipients, will allow them to «transfer» the knowledge, skills and abilities acquired at the process of their studying to further situations of foreign language interaction with native speakers in cross-cultural space.

(C) Ivashkevych Ernest

DOI (article): https://doi.org/10.32626/2227-6246.2021-51.33-53 


\section{Literature}

Гончарук Наталія, Онуфрієва Ліана. Психологічний аналіз рівнів побудови комунікативних дій. Psycholinguistics. Психолінгвістика. Психолингвистика. 2018. Вип. 24 (1). C. 97-117. DOI 10.31470/ 2309-1797-2018-24-1-97-117.

Максименко С., Ткач Б., Литвинчук Л., Онуфрієва Л. Нейропсихолінгвістичне дослідження політичних гасел із зовнішньої реклами. Psycholinguistics. Психолінгвістика. Психолингвистика. 2019. Вип. 26 (1). С. 246-264. DOI 10.31470/2309-1797-2019-26-1246-264. URL : https://psycholing-journal.com/index.php/journal/ article/view/715.

Batel, E. (2020). Context Effect on L2 Word Recognition: Visual Versus Auditory Modalities. Journal of Psycholinguist Research, 49, 223245. URL : https://doi.org/10.1007/s10936-019-09683-6.

Mykhalchuk, N., \& Bihunova, S. (2019). The verbalization of the concept of «fear» in English and Ukrainian phraseological units. Cognitive Studies |Études cognitives, 19, 11. Warsaw (Poland). URL : https:// doi.org/10.11649/cs.2043.

Mykhalchuk, N., \& Ivashkevych, E. (2019). Psycholinguistic Characteristics of Secondary Predication in Determining the Construction of a Peculiar Picture of the World of a Reader. Psycholinguistics. Психолінгвістика. Психолингвистика, 25 (1), 215-231. DOI 10.31470/2309-1797-2019-25-1-215-231.

\section{References}

Honcharuk, Nataliia, \& Onufriieva, Liana (2018). Psykholohichnyi analiz rivniv pobudovy komunikatyvnykh dii [Psychological analysis of the levels of construction of communicative actions]. Psycholinguistics. Psykholinhvistyka. Psikholingvistika - Psycholinguistics. Psycholinguistics. Psycholinguistics, 24 (1), 97-117. DOI 10.31470/23091797-2018-24-1-97-117.

Maksymenko, S., Tkach, B., Lytvynchuk, L., \& Onufriieva, L. (2019). Neiropsykholinhvistychne doslidzhennia politychnykh hasel iz zovnishnoi reklamy [A neuropsycholinguistic research of political slogans from outdoor advertising]. Psycholinguistics. Psykholinhvistyka. Psikholingvistika - Psycholinguistics. Psycholinguistics. Psycholinguistics, 26 (1), 246-264. DOI 10.31470/2309-1797-2019-26-1-246-264. Retrieved from https://psycholing-journal.com/index.php/journal/ article/view/715 [in Ukrainian].

(C) Ivashkevych Ernest

DOI (article): https://doi.org/10.32626/2227-6246.2021-51.33-53 
Batel, E. (2020). Context Effect on L2 Word Recognition: Visual Versus Auditory Modalities. Journal of Psycholinguist Research, 49, 223245. Retrieved from https://doi.org/10.1007/s10936-019-09683-6.

Mykhalchuk, N., \& Bihunova, S. (2019). The verbalization of the concept of "fear" in English and Ukrainian phraseological units. Cognitive Studies | Études cognitives, 19, 11. Warsaw (Poland). Retrieved from https://doi.org/10.11649/cs.2043.

Mykhalchuk, N., \& Ivashkevych, E. (2019). Psycholinguistic Characteristics of Secondary Predication in Determining the Construction of a Peculiar Picture of the World of a Reader. Psycholinguistics. Psykholinhvistyka. Psikholingvistika - Psycholinguistics. Psycholinguistics. Psycholinguistics, 25 (1), 215-231. DOI 10.31470/2309-17972019-25-1-215-231.

Івашкевич Ернест. Психологічні особливості розуміння комунікативної поведінки людей з англомовних країн

\section{АНОТАЦІЯ}

Метою дослідження є визначення психологічних особливостей розуміння комунікативної поведінки людей з англомовних країн.

Методи дослідження. Використано такі загальнонаукові методи, як індукція, дедукція, аналіз і синтез, методи порівняння й опису, метод обгрунтування тощо.

Результати дослідження. Показано, що розуміння комунікативної поведінки людей з англомовних країн в особистості актуалізується через образ, який є не просто результатом уявлення, але зоровим узагальненням, що супроводжує мовленнєву експлікацію думки реципієнтів завдяки вказівним жестам носія мови. У випадку, якщо вказівний жест виокремлює з усієї парадигми сприймання певний об'єкт, що цікавить реципієнта з навколишнього середовища, передусім, ситуативно, то виокремлення, наприклад, частини цього об'єкта щодо окремо обраного або ж сконструйованого простору свідчить про надситуативне його ставлення до певного об'єкта і створення стійкішого способу існування самого об'єкта, крім його зв'язку з вказівним жестом, тобто з руховою активністю реципієнтів. Таким чином вказівний жест трансформується в парадигму умовного простору, подальші перетворення якого фасилітують появу «вказівного поля» у системі розуміння комунікативної поведінки людей з англомовних країн.

C Ivashkevych Ernest

DOI (article): https://doi.org/10.32626/2227-6246.2021-51.33-53 
DOI: https://doi.org/10.32626/2227-6246.2021-51

Висновки. Актуалізація сприймання та розуміння комунікативної поведінки людей з англомовних країн відбувається в умовному просторі, наближеному до реальної життєдіяльності. Ці процеси сприяють тому, що мовленнєва діяльність "групуватиметься" навколо образу і творчих практик. Умовно простір стає парадигмою найбільш значущого і ціннісного змісту, що спочатку уособлював певний образ, спеціально створений носієм мови. Інакше кажучи, виокремлення цього мовленнєвого образу стало підставою для побудови реципієнтами індивідуальної моделі світу. Ритуалізовані реальні дії, що вміщують у своїй структурі «продукцію» всіх видів творчих практик, презентують собою символічну форму первинного образу, який створюється реципієнтами із самого початку сприймання та розуміння комунікативної поведінки людей з англомовних країн.

Ключові слова: комунікативна поведінка, люди з англомовних країн, образ, візуальне узагальнення, побудова індивідуальної моделі світу.

\section{Ивашкевич Эрнест. Психологические особенности понимания коммуни- кативного поведения людей из англоязычных стран}

\section{АННОТАЦИЯ}

Целью исследования является определение психологических особенностей понимания коммуникативного поведения людей из англоязычных стран.

Методы исследования. Использованы такие основные научные методы, как индукция, дедукция, анализ и синтез, методы сравнения и описания, метод обоснования.

Результаты исследования. Показано, что понимание коммуникативного поведения людей из англоязычных стран личностью актуализируется через образ, являющийся не просто результатом представления, но также и зрительным обобщением, которое сопровождает речевую экспликацию мысли реципиентов благодаря указательным жестам носителя языка. В случае, если указательный жест выделяет из всей парадигмы восприятия определенный интересующий реципиента момент, прежде всего, ситуативно, то выделение, например, части этого объекта по отдельности фасилитирует избранное или сконструированное пространство, что свидетельствует о надситуативном отношении реципиента к определенному объекту и создании более устойчивого (C) Ivashkevych Ernest

DOI (article): https://doi.org/10.32626/2227-6246.2021-51.33-53 
DOI: https://doi.org/10.32626/2227-6246.2021-51 2021. випуск 51

способа существования самого объекта, кроме его связи с указательным жестом, то есть с двигательной активностью реципиентов. Таким образом указательный жест трансформируется в парадигму условного пространства, дальнейшие преобразования которого фасилитируют появление "указательного поля» в системе понимания коммуникативного поведения людей из англоязычных стран.

Выводы. Актуализация восприятия и понимания коммуникативного поведения людей из англоязычных стран происходит в условном пространстве, приближенном к реальной жизнедеятельности. Эти процессы способствуют тому, что речевая деятельность будет "группироваться» вокруг образа и творческих практик. Условно пространство становится парадигмой наиболее значимого и ценностного содержания, которое сначала олицетворяло собой определенный образ, специально созданный носителем языка. Иначе говоря, выделение этого речевого образа стало основанием для построения реципиентами индивидуальной модели мира. Ритуализированные реальные действия, содержащие в своей структуре «продукцию» всех видов творческих практик, представляют собой символическую форму первичного образа, который создается реципиентами с самого начала восприятия и понимания коммуникативного поведения людей из англоязычных стран.

Ключевые слова: коммуникативное поведение, люди из англоязычных стран, образ, визуальное обобщение, индивидуальная модель мира.

Original manuscript received December 26, 2020 Revised manuscript accepted February 05, 2021

CC Ivashkevych Ernest

DOI (article): https://doi.org/10.32626/2227-6246.2021-51.33-53 